\title{
Green Synthesis, Anti-cancer and Corrosion Inhibition Activity of $\mathrm{Cr}_{2} \mathrm{O}_{3}$ Nanoparticles
}

\author{
Uma Rani Sharma ${ }^{1}$, Neeraj Sharma ${ }^{2, *(\mathbb{D})}$ \\ 1 Department of Physics, Agra College, Agra, Dr. BRA University, Agra, UP, India \\ 2 Department of Chemistry, GLA University, Mathura, UP, India \\ * Correspondence: neerajsharmagla@gmail.com;
}

Scopus Author ID 57217406885

Received: 3.06.2020; Revised: 15.07.2020; Accepted: 16.07.2020; Published: 23.07.2020

\begin{abstract}
The present study deals with the synthesis of $\mathrm{Cr}_{2} \mathrm{O}_{3}$ nanoparticles (NPs) using Cannabis sativa leaves extract and to assess anti biochemical cancer and corrosion inhibitory activity. The formation of nanoparticles was established by spectrophotometer (UV-vis) at a wavelength of $425 \mathrm{~nm}$ while it was kept for one month at room temperature for stability checking. Dynamic Light Scattering analysis revealed the formation of stable $\mathrm{Cr}_{2} \mathrm{O}_{3}$ NPs measuring 85-90 nm in diameter. Furthermore, $\mathrm{Cr}_{2} \mathrm{O}_{3}$ NPs and Cannabis sativa leaves extract were checked for anti-cancer activity in $\mathrm{HepG}_{2}$ cell lines. The recorded percent cell viability of $\mathrm{HepG}_{2}$ was 64.10 at a minimum concentration $(0.01 \mathrm{ppm})$, whereas at a maximum concentration (10 ppm) it was reduced to $47.25 \%$ after 12 hrs. Further, at 24 hrs, it was reduced up to $21 \%$ and $34.45 \%$ at a minimum and maximum concentrations, respectively. Hence, green synthesized $\mathrm{Cr}_{2} \mathrm{O}_{3}$ NPs possessed promising anti-cancer activity. Loss in weight method is used to evaluate the corrosion inhibition activity on mild steel in $0.5 \mathrm{M} \mathrm{HCl}, \mathrm{HNO}_{3}$, and $\mathrm{NH}_{3}$ solutions. The value of IE also increases with increasing the concentration of $\mathrm{Cr}_{2} \mathrm{O}_{3}$ NPs. It is clear that in basic $\left(\mathrm{NH}_{3}\right)$ medium, $\mathrm{Cr}_{2} \mathrm{O}_{3}$ NPs show the highest inhibition performance of about $89 \%$, and in an acidic medium, it was $80 \%$ at $1.0 \mathrm{~g} / \mathrm{l}$ concentration. The concentration of $\mathrm{Cr}_{2} \mathrm{O}_{3}$ NPs increases with a decrease in the rate of corrosion, which confirmed an increase in the efficiency of inhibition.
\end{abstract}

Keywords: $\mathrm{Cr}_{2} \mathrm{O}_{3} \mathrm{NPs}$; Cannabis sativa; Anti-corrosion; Anti-cancer activity.

(C) 2020 by the authors. This article is an open-access article distributed under the terms and conditions of the Creative Commons Attribution (CC BY) license (https://creativecommons.org/licenses/by/4.0/).

\section{Introduction}

Biofabrication of metal oxide nanoparticles has emerged as an intersecting branch of nanotechnology and biotechnology, which got rapid attention in developing environmentally benign technologies in material synthesis. Metallic nanoparticles are synthesized following diverse routes, including chemical, electrochemical, physical and biological methods, and exhibit unique properties due to larger surface to volume ratio [1-4]. It is true that a large number of methods were beneficial in producing desired nanoparticles with clean and welldefined properties, but at the same time, most of them were quite expensive and toxic to the environment. However, synthesis approaching with biology has proved it to be more costeffective and environment friendly. The concept of biofabrication of nanoparticles was initialized by Raveendran et al. [5] at the beginning of this century by plant product and after that several attempts had been made to synthesize nanoparticles such as silver, gold, platinum, etc. for exploiting antioxidant and reducing properties of plants [6-9]. Recently various plants have been reported for green synthesis of metal nanoparticles gained superiority in biomedical 
fields for various applications, including antibacterial agents [10], anti-inflammatory agents in cosmetics [11], medical devices [12] and in cancer therapy and diagnostics [13].

There are various methods that can opt to choose to control and prevent corrosion damage like blending of production fluids, upgrading materials, chemical inhibitors, and many others $[14,15]$. The corrosion inhibitors are considered best in controlling and preventing the degradation of a metal surface due to corrosion media among all these methods [16,17]. It is a very practical and commercial process used to reduce corrosion. Corrosion inhibitors are of three forms: synthetic, chemical, and natural. The synthetic corrosion inhibitors are found to be good in resisting the corrosion on the metal surfaces, but due to their toxic effects on live cells and environmental regulations made their usage diminishing [18-23].

The usage of plants from decades has been acquired by humans to fulfill their basic requirements towards medicines, flavors, shelters, fertilizers, clothing, foodstuff, corrosion inhibitors, and many more things. It has been reported that in $\mathrm{H}_{2} \mathrm{SO}_{4}$ pickling baths [24], various plant extracts like Chelidonium majus were used. Many researchers have reported various phytochemicals [25-27] and plant extracts [28-41] as hopeful green corrosion inhibitor agents generating heed towards natural corrosion inhibitors.

$\mathrm{Cr}_{2} \mathrm{O}_{3}$ NPs are used in pigments, thermal protection coating, and sensing of humidity $[42,43]$. It has been reported that shape and size play a vital role in the interaction of nanoparticles with biological molecules [44,45]. Before using any compound for the therapeutic purpose, it is important to assess toxicity in normal healthy cells. Similarly, when it is with the nanoparticle, we need to do the same as most of the nanoparticles have some harmful side effects that can have a bad impact on human health. Specifically, it depends on the size of the particle [46]. Inhalation of nanoparticles can lead to oxidative stress that was reported in the literature $[47,48]$. In this report, it was also observed that inflammation could also occur upon inhalation of these nanoparticles in animals. The harmful effects of $\mathrm{Cr}_{2} \mathrm{O}_{3} \mathrm{NPs}$ are a major concern because of their potentiality to alter genetic materials leading to cancer, cell death, and effects on reproduction.DNA strand break or damage is determined by a widely accepted technique comet assay, and it can also help to measure the genotoxicity of xenobiotic compounds. Similarly, this assay is also used to determine the toxic level of different doses of compounds in animals, i.e., carcinogens or genotoxic materials [49-51].

Cannabis sativa (Cannabinaceae family) is a reputed narcotic source and is used as a source of many types of narcotic drugs. Cannabinoids represent the most studied group of compounds, mainly due to their wide range of pharmaceutical effects in humans, including psychotropic activities and other biomedical applications due to their stability and the occurrence of medicinally important terpenes and phenolic compounds and in particular stilbenoids and lignans as capping agents [52].

Based on these above facts, the present work explored the green synthesis of $\mathrm{Cr}_{2} \mathrm{O}_{3} \mathrm{NPs}$ using Cannabis sativa leaves extract and tested there in vitro anti-cancer activity against $\mathrm{HepG}_{2}$ cell line and corrosion inhibition effect.

\section{Materials and Methods}

The leaves of Cannabis sativa were collected from the outer region of Agra, Uttar Pradesh, India. Chromium nitrate nonahydrate $\left[\mathrm{Cr}\left(\mathrm{NO}_{3}\right)_{3} .9 \mathrm{H}_{2} \mathrm{O}\right.$ ], liquid $\mathrm{NH}_{3}, \mathrm{HCl}$ and $\mathrm{HNO}_{3}$ were purchased from Sigma-Aldrich. All the reagents were attained from Hi-Media, India, to investigate cytotoxicity assay. 


\subsection{Preparation of aqueous extract.}

The plants' leaves were collected and then sterilized carefully with distilled water so as to remove the narcotic and epiphytes plants. The leaves were dried for 10 days in shade and were ground using a home blender to form a fine powder. A sufficient amount of plant material (powder) was filled in the porous cellulose thimble (An average of $20 \mathrm{gm}$ extract in a $25 \times 80$ $\mathrm{mm}$ thimble was used). Thimble is placed inside the soxhlet extractor shown in Figure 1. Thereafter, in the round bottom flask linked to a soxhlet extractor and condenser on an isomantle, solvent (500 $\mathrm{ml}$ of water) was added. After the completion of the process, the rotary evaporator was used to dry the water, and a little amount (about two to three ml) of extracted material was left within the flask.

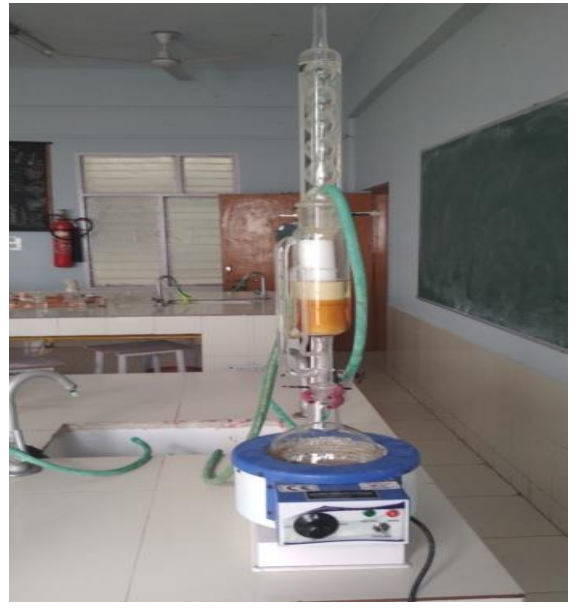

Figure 1. Extraction of plant leaves extracts using soxhlet extractor unit.

\subsection{Synthesis and Characterization of $\mathrm{Cr}_{2} \mathrm{O}_{3} \mathrm{NPs}$.}

At room temperature, $90 \mathrm{ml}$ of $1 \mathrm{mM}$ aqueous [Cr( $\left(\mathrm{NO}_{3}\right)_{3} .9 \mathrm{H}_{2} \mathrm{O}$ ] was mixed in $10 \mathrm{ml}$ of $5 \%$ filtrate of leaves extract by constant stirring on a magnetic stirrer for about $1 \mathrm{~h}$. UV-vis spectral analysis confirmed the formation of $\mathrm{Cr}_{2} \mathrm{O}_{3}$ NPs by showing a color change. The monitoring of bioreduction of the $\mathrm{Cr}^{3+}$ ions in solutions was done by diluting $0.5 \mathrm{ml}$ of sample to $4.5 \mathrm{ml}$ of water using a spectrophotometer (Systronics 2203) by examining in the range 300 $\mathrm{nm}$ to $700 \mathrm{~nm}$. FTIR Tracer-100 (Shimadzu) was used to study structural analysis of the $\mathrm{Cr}_{2} \mathrm{O}_{3}$ NPs in the range of $400-4000 \mathrm{~cm}^{-1}$. The size distribution of $\mathrm{Cr}_{2} \mathrm{O}_{3} \mathrm{NPs}$, along with the polydispersity index, was determined using Dynamic Light Scattering (DLS) and Zeta potential using Malvern Zeta sizer Nano ZS90 at Nanotechnology lab GLA University, Mathura.

\subsection{Cell viability assay.}

Dulbecco's modified Eagle's medium accompanied by $100 \mathrm{U} / \mathrm{mL}$ penicillin, $100 \mu \mathrm{g} / \mathrm{mL}$ streptomycin, and $10 \%$ heat-inactivated fetal bovine serum was used to culture the $\mathrm{HepG}_{2}$ cells at International Centre for Genetic Engineering and Biotechnology, New Delhi. 96 well plates were taken in which 15,000 cells of $\mathrm{HepG}_{2}$ cells were implanted in each well, and at $37^{\circ} \mathrm{C}$ were incubated overnight. Nikon Eclipse TS-100 phase-contrast microscope was used to observe the size and shape of cells before and after exposure to $\mathrm{Cr}_{2} \mathrm{O}_{3}$ NPs. In the culture plate, the supernatants were drawn out after overnight growth. Thereafter, the different concentrations such as $0.01,0.1,1$, and 10 ppm of $\mathrm{Cr}_{2} \mathrm{O}_{3}$ NPs and standard solutions diluted by double distilled water were added to $\mathrm{HepG}_{2}$ cells, and modified MTT assay was used to track the cell viability [53]. After treating the cells with $\mathrm{Cr}_{2} \mathrm{O}_{3}$ NPs the morphology of cells was observed using an 
inverted microscope. After 24 hours, the supernatant was drawn out, and a $10 \mu \mathrm{L}$ test solution accompanied with $90 \mu \mathrm{L}$ of culture medium was added to each well, and incubation of plates was done for four hours. Afterward, the supernatant was replaced by $100 \mu \mathrm{L}$ DMSO and ELISA reader was used to observe the absorbance at $570 \mathrm{~nm}$. For every treatment, while the withdrawal of the blank, the untreated control cells were counted to calculate the percent cell viability. The below-given formula is used to calculate the number of cell viable with respect to control:

$$
\frac{[O D]_{\text {test }}}{[O D]_{\text {control }}} \times 100
$$

\subsection{Anti-corrosion activity.}

Loss in weight method has been used to study inhibition property. The experiment was performed using a square mild steel specimen having holes on the upper edge. Each specimen was weighed using an analytical balance of $0.0001 \mathrm{gm}$ accuracy. These specimens were suspended in a beaker containing $100 \mathrm{ml}$ test solution with and without a different concentration of $\mathrm{Cr}_{2} \mathrm{O}_{3}$ NPs solution. All these beakers were placed in thermostat so that the temperature of the beaker solution becomes constant. After 48 hours, all beakers were taken out from thermostat; each suspended specimen was washed, dried, and weighed again. Inhibition study was carried out at three different temperatures 303, 313, and $323 \mathrm{~K}$. Experiment was repeated using different concentrations of $\mathrm{Cr}_{2} \mathrm{O}_{3} \mathrm{NPS}$ at different temperature ranges. Duplicate sets of every experiment were performed so that accurate values of weight loss could be calculated. Weight loss value has been used to calculate the corrosion rate, inhibition efficiency, activation energy, enthalpy, entropy, and Gibbs free energy.

\subsection{Measurement of loss in weight.}

The corrosion rate can be determined simply and accurately using loss in weight analysis. A sample of mild steel was weighed and kept in a corrosive environment for a time interval and later was removed. The entire corrosive product was cleaned from the sample and was reweighed. Loss in weight of mild steel specimen after dipping in test solution with and without extracts in different concentrations was calculated. The relation between the loss in weight and an average rate of corrosion $\left(\mathrm{mg} \mathrm{cm}^{-2} \mathrm{~h}^{-1}\right)$ is:

$$
C R=\frac{\Delta w}{A . t}
$$

Where,

$\mathrm{CR}=$ Rate of corrosion,

$\Delta \mathrm{w}=$ loss in weight of sample,

$\mathrm{A}=$ Total area of specimen and

$\mathrm{t}=$ time of immersion,

The loss in weight monitoring is the most favorable technique for slow corrosion on metal and accepted average data. The equation given below was used to calculate the percentage inhibition efficiency for the samples [54].

$$
I E=\frac{W_{o}-W}{W_{o}} \times 100
$$

Where,

I.E. = Inhibition efficiency, 
$\mathrm{W}_{0}=$ Weight loss in the absence of inhibitor and

$\mathrm{W}=\mathrm{Weight}$ loss in the presence of inhibitor

\section{Results and Discussion}

FTIR spectroscopy plays a very crucial role in identifying inorganic and organic species with low content. Figure 2 delineates the FTIR spectrum of $\mathrm{Cr}_{2} \mathrm{O}_{3}$ NPs synthesized by Cannabis sativa plant leaves extract. FTIR spectrum of as-synthesized $\mathrm{Cr}_{2} \mathrm{O}_{3} \mathrm{NPs}$ has the characteristic absorption band in the range of $548 \mathrm{~cm}^{-1}$ represents the $\mathrm{Cr}-\mathrm{O}$ bond. The other weak absorption bands in all spectra of $\mathrm{Cr}_{2} \mathrm{O}_{3} \mathrm{NPs}$ in the range of $3420 \mathrm{~cm}^{-1}$ correspond to the hydroxyl group of water.

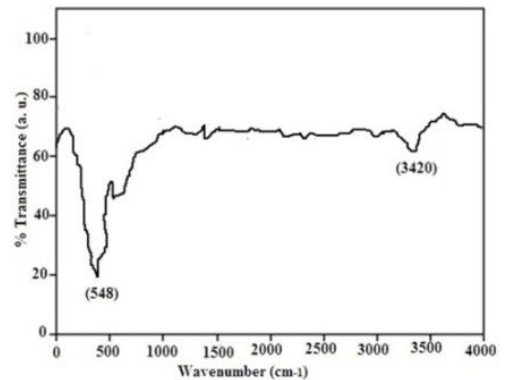

Figure 2. FTIR Spectrum of $\mathrm{Cr}_{2} \mathrm{O}_{3}$ NPs.

The confirmation of green synthesis of $\mathrm{Cr}_{2} \mathrm{O}_{3}$ NPs using Cannabis sativa leaves extract was initially established with an expeditious change from green to brown color and, thereafter, confirmed in a range of wavelengths from 300 to $700 \mathrm{~nm}$ using a spectrophotometer. The result showed the presence of a peak at $425 \mathrm{~nm}$, signifying the formation of $\mathrm{Cr}_{2} \mathrm{O}_{3} \mathrm{NPs}$ (Figure 3). The stability analysis of these $\mathrm{Cr}_{2} \mathrm{O}_{3}$ NPs was also performed at room temperature, and Leaves extract of Cannabis sativa- $\mathrm{Cr}_{2} \mathrm{O}_{3}$ NPs were found to be stable for one month with no specific spectral peak shift (Figure $4 \mathrm{a}$ and $\mathrm{b}$ ).

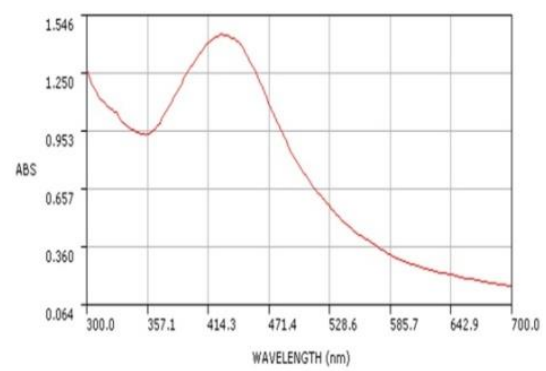

Figure 3. UV-vis spectra of $\mathrm{Cr}_{2} \mathrm{O}_{3}$ NPs at $425 \mathrm{~nm}$ after 4 hrs of incubation at room temperature.

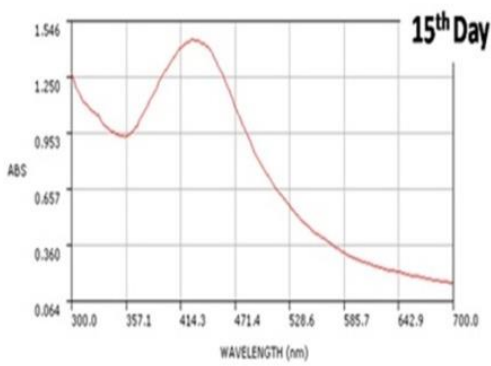

(a)

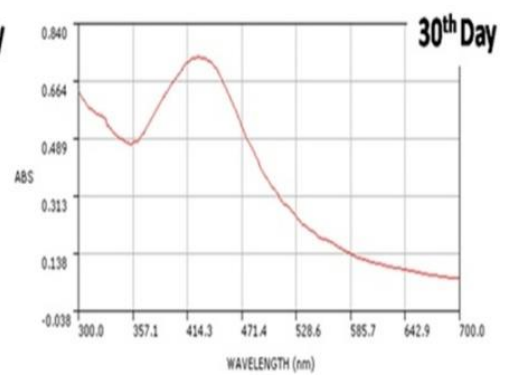

(b)

Figure 4. Stability analyses of $\mathrm{Cr}_{2} \mathrm{O}_{3}$ NPs at room temperature after (a) 15 days (b) 30 days. 
Excitation of surface plasmon resonance due to MO NPs [55] and reduction of metal ion plays a crucial role in the color change. In this research paper, the stability and polydispersity index had been monitored, and the recorded results showed that due to the presence of ferulic acid and phenols in Cannabis sativa leaves extract acts as reducing and capping agents, thus giving synthesized $\mathrm{Cr}_{2} \mathrm{O}_{3}$ NPs extra shelf-life. Tripathy et al. [56] has synthesized MO NPS using Azadirachta indica leaves extract to optimize the various parameters such as interaction time, the concentration of extract and mixing ratio, and also explained that shape and size of green synthesized nanoparticles are closely related to optimization of various parameters. Size distribution and polydisperse nature of fabricated $\mathrm{Cr}_{2} \mathrm{O}_{3}$ NPs were observed using DLS analysis, and their size was found in the range of 85-90 $\mathrm{nm}$ (Figure 5). Also, confirmed from the UV-vis study. Moreover, at room temperature for about one month, their Polydispersity Index (PDI) was noticed (Figure $6 \mathrm{a}$ and $\mathrm{b}$ ).

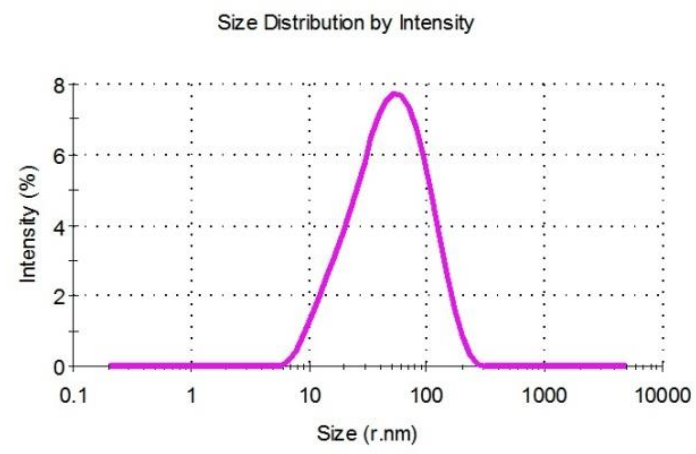

Figure 5. DLS size distribution of $\mathrm{Cr}_{2} \mathrm{O}_{3}$ NPs of incubation at room temperature after 4 hrs.

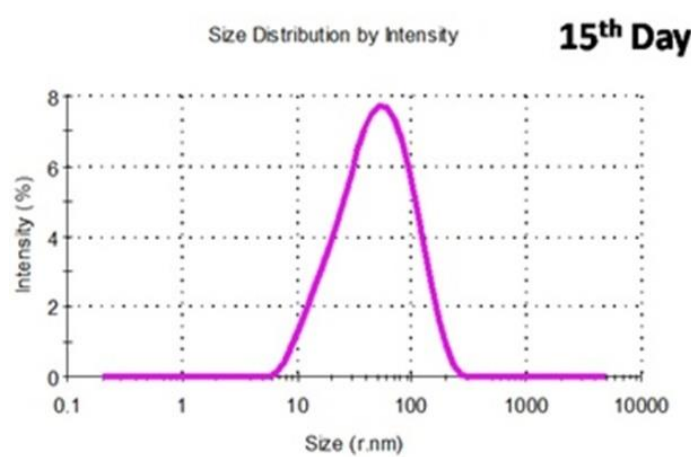

(a)

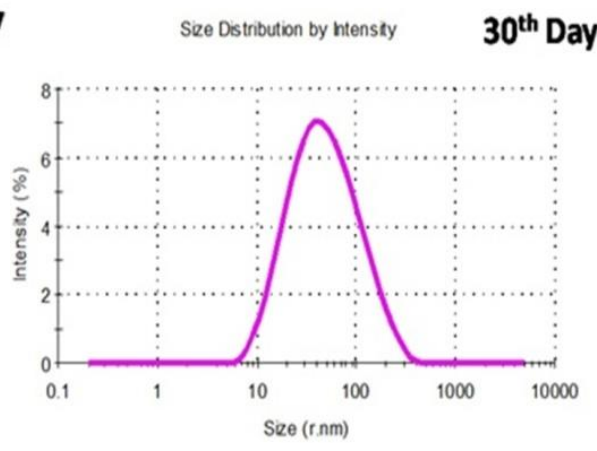

(b)

Figure 6. DLS size distribution of $\mathrm{Cr}_{2} \mathrm{O}_{3}$ NPs at room temperature after (a) 15 days (b) 30 days.

These $\mathrm{Cr}_{2} \mathrm{O}_{3}$ NPs were found to be polydispersed throughout the period of one month, with PDI recorded to be near about 0.3 (Table 1). The PDI values for $\mathrm{Cr}_{2} \mathrm{O}_{3}$ NPs were found to be around 0.3, which is befitting for pharmaceutical applications while the common PDI values range from $0-1$. The phytochemicals such as glycosides, tannins, flavonoids, and terpenoids and crystallization of the bio-organic phase on the surface of the $\mathrm{Cr}_{2} \mathrm{O}_{3} \mathrm{NPs}$ attribute to the stability of $\mathrm{Cr}_{2} \mathrm{O}_{3} \mathrm{NPs}-$ Cannabis sativa also reported in the synthesis of MO NPs by Citrus limon and Coleus aromaticus leaves extract [57,58].

Table 1. Size distribution and PDI values of $\mathrm{Cr}_{2} \mathrm{O}_{3}$ NPs-Cannabis sativa at room temperature.

\begin{tabular}{l|l|l} 
Days & Size $(\mathbf{n m})$ & Polydispersity Index (PDI) \\
\hline $15^{\text {th }}$ Day & 88 & 0.305 \\
\hline $30^{\text {th }}$ Day & 89 & 0.308
\end{tabular}


The anti-cancer activity of $\mathrm{Cr}_{2} \mathrm{O}_{3}$ NPs was tested in $\mathrm{HepG}_{2}$ cells and was found that at $10 \mathrm{ppm}$ and $0.01 \mathrm{ppm}$ concentration, the cell viability was $47.25 \%$ and $64.10 \%$ respectively after $12 \mathrm{hr}$ while it decreases to $16.75 \%$ and $21 \%$ respectively after $24 \mathrm{~h}$ shown in figure 7 . Also observed the cell shrinkage and spread at higher concentration and lower concentrations respectively accompanied with irregular shape in figure 8 . While observing through an inverted microscope at high concentration, the cells appeared to be necrotic and were detached from the culture dishes after $48 \mathrm{hr}$.

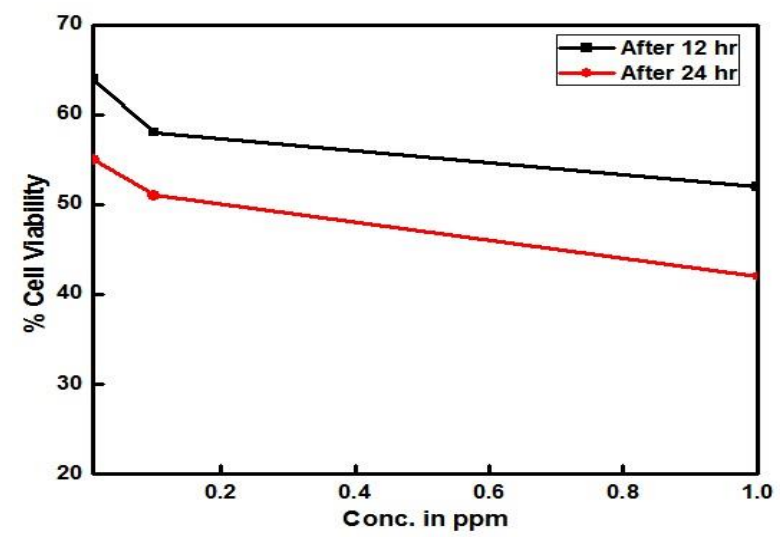

Figure 7. Cell viability measured by MTT assays on $\mathrm{HepG}_{2}$ cell lines after 12 and 24 h exposure to doses of $\mathrm{Cr}_{2} \mathrm{O}_{3}$ NPs.

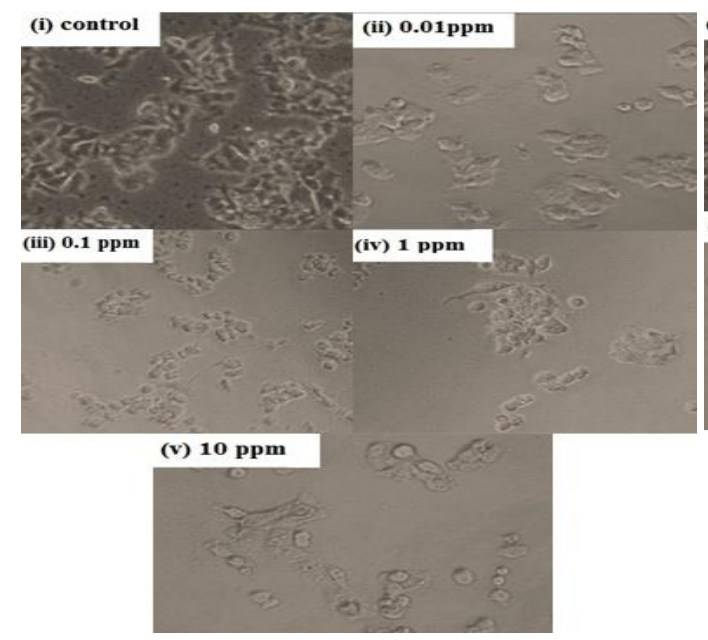

(a)

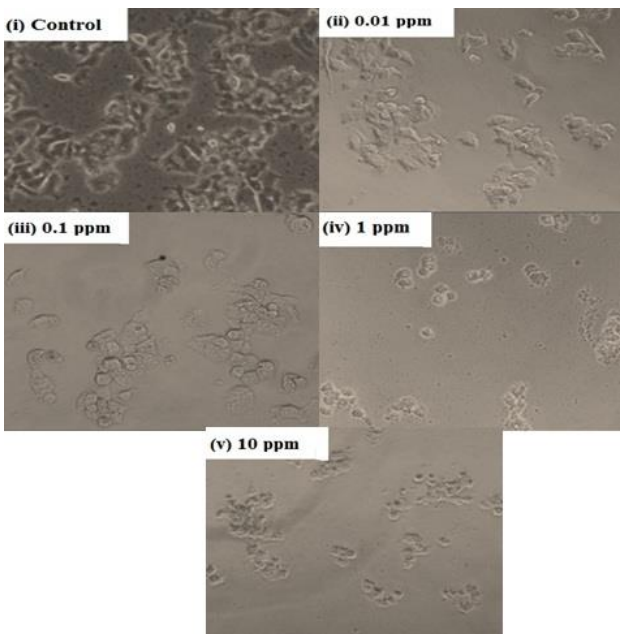

(b)

Figure 8. Cytotoxic effect of different concentrations of $\mathrm{Cr}_{2} \mathrm{O}_{3} \mathrm{NP}$ after (a) $12 \mathrm{hr}$ (b) $24 \mathrm{hr}$.

The anti-cancer activity was observed by high cell mortality of $\mathrm{HepG}_{2}$ cells on interaction with $\mathrm{Cr}_{2} \mathrm{O}_{3} \mathrm{NPs}$ in the range of $85-90 \mathrm{~nm}$. Also, it was observed that the cell viability in $\mathrm{HepG}_{2}$ cells depends on the concentration of $\mathrm{Cr}_{2} \mathrm{O}_{3} \mathrm{NPs}$ and supported in the previous literature [59,60]. The synergistic consequence of phytochemicals present in Cannabis sativa leaves extract might be the cause of inhibitory effect against $\mathrm{HepG}_{2}$ cell line shown by $\mathrm{Cr}_{2} \mathrm{O}_{3}$ NPs.

The rate of corrosion has been determined after $48 \mathrm{hr}$ on mild steel samples at a temperature range from 303 to $323 \mathrm{~K}$. The rate of corrosion and \% of IE measured by loss in weight process using various concentrations of $\mathrm{Cr}_{2} \mathrm{O}_{3} \mathrm{NPs}$ in an acidic and basic medium at a temperature range from 303 to $333 \mathrm{~K}$ are mentioned in table 2. 
Table 2. Rate of Corrosion and IE of $\mathrm{Cr}_{2} \mathrm{O}_{3} \mathrm{NPs}$ for mild steel.

\begin{tabular}{|c|c|c|c|c|c|c|c|c|c|c|c|}
\hline \multirow{2}{*}{ Sampls } & \multirow{2}{*}{ Medim } & \multirow{2}{*}{$\begin{array}{l}\text { Temp. } \\
\text { (K) } \\
\begin{array}{l}\text { Conc. } \\
(\mathbf{p p m})\end{array}\end{array}$} & \multicolumn{3}{|l|}{303} & \multicolumn{3}{|l|}{313} & \multicolumn{3}{|l|}{323} \\
\hline & & & $\begin{array}{l}\text { Loss in } \\
\text { Wt. }\end{array}$ & $\begin{array}{l}\text { Rate of } \\
\text { Corr. }\end{array}$ & IE & $\begin{array}{l}\text { Loss in } \\
\text { Wt. }\end{array}$ & $\begin{array}{l}\text { Rate of } \\
\text { Corr. }\end{array}$ & IE & $\begin{array}{l}\text { Loss } \\
\text { in Wt. }\end{array}$ & $\begin{array}{l}\text { Rate of } \\
\text { Corr. }\end{array}$ & IE \\
\hline \multirow{15}{*}{$\begin{array}{l}\mathrm{Cr}_{2} \mathrm{O}_{3} \\
\mathrm{NPs}\end{array}$} & \multirow{5}{*}{$\mathrm{HCl}$} & Blank & 0.017 & 0.088 & 0.000 & 0.020 & 0.102 & 0.000 & 0.024 & 0.126 & 0.000 \\
\hline & & 250 & 0.010 & 0.053 & 39.881 & 0.014 & 0.074 & 38.028 & 0.018 & 0.091 & 37.714 \\
\hline & & 500 & 0.006 & 0.029 & 44.554 & 0.010 & 0.052 & 43.434 & 0.012 & 0.065 & 41.129 \\
\hline & & 750 & 0.003 & 0.016 & 46.429 & 0.007 & 0.036 & 43.478 & 0.009 & 0.045 & 44.186 \\
\hline & & 1000 & 0.001 & 0.003 & 80.000 & 0.004 & 0.020 & 81.579 & 0.005 & 0.026 & 72.000 \\
\hline & \multirow{5}{*}{$\mathrm{HNO}_{3}$} & Blank & 0.024 & 0.123 & 0.000 & 0.023 & 0.121 & 0.000 & 0.023 & 0.121 & 0.000 \\
\hline & & 250 & 0.017 & 0.087 & 41.317 & 0.017 & 0.086 & 40.361 & 0.017 & 0.087 & 39.521 \\
\hline & & 500 & 0.011 & 0.059 & 47.788 & 0.012 & 0.060 & 44.348 & 0.012 & 0.061 & 42.735 \\
\hline & & 750 & 0.007 & 0.035 & 66.176 & 0.007 & 0.036 & 64.286 & 0.007 & 0.038 & 62.500 \\
\hline & & 1000 & 0.004 & 0.020 & 78.947 & 0.004 & 0.021 & 75.000 & 0.004 & 0.022 & 67.442 \\
\hline & \multirow{5}{*}{$\mathrm{NH}_{3}$} & Blank & 0.020 & 0.103 & 0.000 & 0.021 & 0.109 & 0.000 & 0.026 & 0.136 & 0.000 \\
\hline & & 250 & 0.009 & 0.045 & 56.566 & 0.014 & 0.073 & 48.227 & 0.018 & 0.093 & 47.191 \\
\hline & & 500 & 0.003 & 0.016 & 63.953 & 0.009 & 0.046 & 60.227 & 0.011 & 0.058 & 58.929 \\
\hline & & 750 & 0.001 & 0.005 & 70.968 & 0.006 & 0.029 & 60.000 & 0.007 & 0.037 & 57.746 \\
\hline & & 1000 & 0.000 & 0.001 & 88.889 & 0.003 & 0.016 & 77.419 & 0.004 & 0.021 & 73.171 \\
\hline
\end{tabular}

The value of IE of nanoparticles of $\mathrm{Cr}_{2} \mathrm{O}_{3}$ synthesized by Cannabis sativa leaves extract solution has been calculated using weight loss measurement after $48 \mathrm{~h}$ of immersion at various temperatures ranging from 303 to $323 \mathrm{~K}$. In the blank sample, no nanoparticles of $\mathrm{Cr}_{2} \mathrm{O}_{3}$ solution were used, and other solutions contained a concentration of 250, 500, 750, and 1000 ppm of nanoparticles of $\mathrm{Cr}_{2} \mathrm{O}_{3}$. Table 2 shows the calculated values of inhibition efficiency and corrosion rate in acidic $\left(\mathrm{HCl}, \mathrm{HNO}_{3}\right)$ and basic $\left(\mathrm{NH}_{3}\right)$ medium. The value of IE also increases with increasing the concentration of nanoparticles of $\mathrm{Cr}_{2} \mathrm{O}_{3}$. It is clear from that in a basic medium, all $\mathrm{Cr}_{2} \mathrm{O}_{3}$ NPs show maximum inhibition efficiency. $\mathrm{Cr}_{2} \mathrm{O}_{3} \mathrm{NPs}$ show a maximum efficiency of $89 \%$ in basic medium and $80 \%$ in an acidic medium at $1.0 \mathrm{~g} / \mathrm{l}$ concentration. The concentration of $\mathrm{Cr}_{2} \mathrm{O}_{3}$ NPS increases with a decrease in the rate of corrosion, which confirmed an increase in the efficiency of inhibition.

\section{Conclusions}

The $\mathrm{Cr}_{2} \mathrm{O}_{3}$ NPs synthesized using Cannabis sativa leaves extract was found to be anticancerous in nature against $\mathrm{HepG}_{2}$ cell line and were stable for one month. Therefore, $\mathrm{Cr}_{2} \mathrm{O}_{3}$ NPs synthesized using plant extract could be substantiated as a preferable source of treatment against cancer.

The outcomes of anti-corrosion activity revealed that inhibition efficiency decreases on increasing temperature because of the desorption of inhibitor molecules on the metal surface. The maximum inhibition efficiency was shown at $303 \mathrm{~K}$ temperature for $\mathrm{Cr}_{2} \mathrm{O}_{3} \mathrm{NPs}$. The value of IE decreases with an increase in the temperature from 303 to $323 \mathrm{~K}$ from $89 \%$ to $73 \%$ in basic $\left(\mathrm{NH}_{3}\right)$ medium.

\section{Funding}

This research received no external funding.

\section{Acknowledgments}

The authors express immense thanks to Dr. D K Das, Assistant Professor, Department of Chemistry, of GLA University, Mathura, India, and Dr. D V Singh Head, Department of Physics, Agra College, Agra, India for their valuable suggestions, assistance and encouragements during this work. 


\section{Conflicts of Interest}

\section{The authors declare no conflict of interest.}

\section{References}

1. Lee, Y.J.; Song, K.; Cha, S.H.; Cho, S.; Kim, Y.S.; Park, Y. Sesqui terpenoids from Tussilago farfara flower bud extract for the eco-friendly synthesis of silver and gold nanoparticles possessing antibacterial and anticancer activities. Nanomaterials2019, 9, https://doi.org/10.3390/nano9060819.

2. Abdallah, Y.; Ogunyemi, S.O.; Abdelazez, A.; Zhang, M.; Hong, X.; Ibrahim, E.; Hossain, A.; Fouad, H.; $\mathrm{Li}, \mathrm{B}$.; Chen, J. The green synthesis of MgO nano-flowers using Rosmarinus cinalis L. (Rosemary) and the antibacterial activities against Xanthomonas oryzae pv. Oryzae. Bio. Med. Res. Int. 2019 , 2019,https://doi.org/10.1155/2019/5620989.

3. Varadavenkatesan, T.; Selvaraj, R.; Vinayagam, R. Dye degradation and antibacterial activity of green synthesized silver nanoparticles using Ipomoea digitata Linn. flower extract. Int. J. Environ. Sci. Te.2019, 16, 2395-2404, https://doi.org/10.1007/s13762-018-1850-4.

4. Lakshmeesha, T.R.; Kalagatur, N.K.; Mudili, V.; Mohan, C.D.; Rangappa, S.; Prasad, B.D.; Ashwini, B.S.; Hashem, A.; Alqarawi, A.A.; Malik, J.A. Biofabrication of zinc oxide nanoparticles with Syzygium aromaticum flower buds extract and finding its novel application in controlling the growth and mycotoxins of Fusarium graminearum. Front. Microbiol. 2019, 10, 1244, https://doi.org/10.3389/fmicb.2019.01244.

5. Raveendran, P.; Fu, J.; Wallen, S.L. Green Synthesis and Stabilization of Metal Nanoparticles. Journal of the American Chemical Society2003,125, 13940-13941, https://doi.org/10.1021/ja029267j.

6. Sarah, S.L.R.; Iyer, P.R. Green synthesis of copper nanoparticles from the flowers of Mimusops elengi. Int. J. Recent. Sci. Res. 2019, 10, 32956-32963.

7. Sultan, M.; Waheed, A.; Bibi, I.; Islam, A. Ecofriendly reduction of methylene blue with polyurethane catalyst. Int. J. Polym Sci. 2019, 2019,https://doi.org/10.1155/2019/3168618.

8. Begum, R.; Najeeb, J.; Sattar, A.; Naseem, K.; Irfan, A.; Al-Sehemi, A.G.; Farooqi, Z.H. Chemical reduction of methylene blue in the presence of nanocatalysts: A critical review. Rev. Chem. Eng. 2019.

9. Matus, K.J.M.; Hutchison, J.E.; Peoples, R.; Rung, S.; Tanguay, R.L. Green Nanotechnology Challenges and Opportunities. Available online: https://greennano.org/sites/greennano2.uoregon.edu/files/GCI_WP_GN10.pdf (accessed on 2 November 2019).

10. Singh, A.K.; Rathod, V.; Singh, D.; Ninganagouda, S.; Kulkarni, P.; Mathew, J.; Haq, M.U. Bioactive silver nanoparticles from endophytic fungus Fusarium sp. isolated from an ethanomedicinal plant Withania somnifera (Ashwagandha) and its antibacterial activity. Int. J. Nanomater. Biostruct.2015, 5, 15-19.

11. Kokura, S.; Handa, O.; Takagi, T.; Ishikawa, T.; Naito, Y.; Yoshikawa, T. Silver Nanoparticles as a Safe Preservative for Use in Cosmetics, Nanomedicine: Nanotechnology, Biology, \& Medicine2010, 6, 570574,https://doi.org/10.1016/j.nano.2009.12.002.

12. Martinez-Gutierrez, F.; Olive, P.L.; Banuelos, A.; Orrantia, A.; Nino, N.; Sanchez, E.M.; Av-Gay, Y. Synthesis, Characterization, and Evaluation of Antimicrobial and Cytotoxic Effect of Silver and Titanium Nanoparticles. Nanomedicine: Nanotechnology, Biology and Medicine2010, 6, 681681,https://doi.org/10.1016/j.nano.2010.02.001.

13. Ovais, M.; Khalil, A.T.; Raza, A.; Khan, M.A.; Ahmad, I.; Islam, N.U.; Shinwari, Z. Green synthesis of silver nanoparticles via plant extracts: beginning a new era in cancer theranostics.Nanomedicine2016, 12, 3157-3177,https://doi.org/10.2217/nnm-2016-0279.

14. Dudukcu, M.; Yazici, B.; Erbil, M. The effect of indole on the corrosion behaviour of stainless steel. Mater. Chem. Phys.2004, 87, 138-141,https://doi.org/10.1016/j.matchemphys.2004.05.043.

15. Galal, A.; Atta, N.F.; Al-Hassan, M.H.S. Effect of some thiophene derivatives on the electrochemical behavior of AISI 316 austenitic stainless steel in acidic solutions containing chloride ions: II. Effect of temperature and surface studies. Mater. Chem. Phys. 2005, 89, 2838,https://doi.org/10.1016/j.matchemphys.2004.08.018.

16. De Souza, F.S.; Spinelli, A. Cafeic acid as a green corrosion inhibitor for mild steelA. Corros. Sci.2009, 51, 642-649,https://doi.org/10.1016/j.corsci.2008.12.013.

17. Raja, P.B.; Sethuraman, M.G. Inhibitive effect of Xylopia ferruginea extract on the corrosion of mild steel in 1M HCl medium. Mater. Lett. 2008, 62, https://doi.org/10.1007/s12613-011-0455-4.

18. Aljuhani, A.; El-Sayed, W.S.; Sahu, P.K.; Rezki, N.; Aouad, M.R.; Salghi, R.; Messali, M. Microwaveassisted synthesis of novel imidazolium, pyridinium and pyridazinium-based ionic liquids and/or salts and prediction of physico-chemical properties for their toxicity and antibacterial activity. J. Mol. Liq. 2018, 249, 747-753,https://doi.org/10.3390/molecules23071727.

19. Goyal, M.; Kumar, S.; Bahadur, I.; Verma, C.; Ebenso, E.E. Organic corrosion inhibitors for industrial cleaning of ferrous and non-ferrous metals in acidic solutions: a review. J. Mol. Liq. 2018, 256, 565573,https://doi.org/10.1016/j.molliq.2018.02.045. 
20. Abd El-Maksoud, S.A.A. The effect of hexadecyl pyridinium bromide and hexadecyl trimethyl ammonium bromide on the behaviour of iron and copper in acidic solutions. J. Electroanal. Chem. 2004, 565, 321-328, https://doi.org/10.1016/j.jelechem.2003.10.026.

21. Alibakhshi, E.; Ramezanzadeh, M.; Bahlakeh, G.; Ramezanzadeh, B.; Mahdavian, M.; Motamedi, M. Glycyrrhiza glabra leaves extract as a green corrosion inhibitor for mild steel in $1 \mathrm{M}$ hydrochloric acid solution: experimental, molecular dynamics, Monte Carlo and quantum mechanics study. J. Mol. Liq. 2018, 255, 185-198,https://doi.org/10.1016/j.molliq.2018.01.144.

22. El-Hajjaji, F.; Messali, M.; Aljuhani, A.; Aouad, M.; Hammouti, B.; Belghiti, M.; Chauhan, D.; Quraishi, M. Pyridazinium-based ionic liquids as novel and green corrosion inhibitors of carbon steel in acid medium: electrochemical and molecular dynamics simulation studies. J. Mol. Liq. 2018, 249, 9971008,https://doi.org/10.1016/j.molliq.2017.11.111.

23. Nishimura, R.; Maeda, Y. Stress corrosion cracking of type 304 austenitic stainless steel in sulphuric acid solution including sodium chloride and chromate. Corros. Sci. 2004, 46, 343360,https://doi.org/10.1016/S0010-938X(03)00154-9.

24. Sanyal, B. Organic compounds as corrosion inhibitor in different environment- A review. Prog. Org. Coat. 1981, 9, https://doi.org/10.1016/0033-0655(81)80009-X.

25. Abdel Gaber, A.M.; Abd EL Nabey, B.A.; Saadawy, M. The role of acid anion on the inhibition of the acidic corrosion of steel by lupine extract. Corros. Sci. 2009, 51, 10381042,https://doi.org/10.1016/j.corsci.2009.03.003.

26. Oguzie, E.E. Corrosion inhibition of aluminium in acidic and alkaline media by Sansevieria trifasciata extract. Corros. Sci. 2007, 49, 1527-1539,https://doi.org/10.1016/j.corsci.2006.08.009.

27. Awad, M.I. Eco friendly corrosion inhibitors: Inhibitive action of quinine for corrosion of low carbon steel in $1 \mathrm{~m} \mathrm{HCl}$. J. Appl. Electrochem. 2006, 36, 1163-1168, https://doi.org/10.1007/s10800-006-9204-1.

28. Alvarez, P.E.; Fiori-Bimbi, M.V.; Neske, A.; Brandán, S.A.; Gervasi, C.A. Rollinia occidentalis extract as green corrosion inhibitor for carbon steel in $\mathrm{HCl}$ solution. J. Ind. Eng. Chem. 2015, 92, 192199,https://doi.org/10.1016/j.jiec.2017.09.012.

29. Chetouani, A.; Hammouti, B. Corrosion inhibition of iron in hydrochloric acid solutions by naturally Henna. Bull. Electrochem. 2003, 19, 23-26.

30. Verma, C.; Ebenso, E. E.; Bahadur, I.; Quraishi, M.A. An overview on plant extracts as environmental sustainable and green corrosion inhibitors for metals and alloys in aggressive corrosive media. J. Mol. Liq. 2018, 266, 577-590,https://doi.org/10.1016/j.molliq.2018.06.110.

31. Haldhar, R.; Prasad, D.; Bhardwaj, N. Extraction and experimental studies of Citrus aurantifolia as an economical and green corrosion inhibitor for mild steel in acidic media. J. Adhes. Sci. Technol. 2019, 33, 1169-1183,https://doi.org/10.1080/01694243.2019.1585030.

32. Abdel-Gaber, M.; Abd-El-Nabey, B.A.; Sidahmed, I.M.; El-Zayaday, A.M.; Saadawy, M. Inhibitive action of some plant extracts on the corrosion of steel in acidic media. Corros. Sci. 2006, 48, 27652779,https://doi.org/10.1016/j.corsci.2005.09.017.

33. Benabdellah, M.; Benkaddour, M.; Hammouti, B.; Bendahhou, M.; Aouniti, A. Inhibition of steel corrosion in $2 \mathrm{M} \quad \mathrm{H}_{3} \mathrm{PO}_{4}$ by artemisia oil. Surf. Sci. 2006, 252, $6212-$ 6217,https://doi.org/10.1016/j.apsusc.2005.11.066.

34. Alibakhshi, E.; Ramezanzadeh, M.; Bahlakeh, G.; Ramezanzadeh, B.; Mahdavian, M.; Motamedi, M. Glycyrrhiza glabra leaves extract as a green corrosion inhibitor for mild steel in $1 \mathrm{M}$ hydrochloric acid solution: experimental, molecular dynamics. J. Mol. Liq. 2018, 255, 185198,https://doi.org/10.1016/j.molliq.2018.01.144.

35. Umoren, S.A.; Solomon, M.M.; Obot, I.B.; Sulieman, R.K. A critical review on the recent studies on plant biomaterials as corrosion inhibitors for industrial metals. J. Ind. Eng. Chem. 2019, 76, 91115,https://doi.org/10.1016/j.jiec.2019.03.057.

36. Abiola, O.K.; Oforka, N.C.; Ebenso, E.E.; Nwinuka, N.M. Eco-friendly corrosion inhibitors: Inhibitive action of Delonix `regia extract for the corrosion of aluminium in acidic medium. Anti-Corros. Meth. Mater. 2007, 54, 219-224, https://doi.org/10.1108/00035590710762357.

37. Oguzie, E.E. Studies on the inhibitive effect of Occimum viridis extract on the acid corrosion of mild steel. Mater. Chem. Phys. 2006, 99, 441-446,https://doi.org/10.1016/j.matchemphys.2005.11.018.

38. Raja, P.B.; Sethuramam, M.G. Strychnos nux vomica an eco-friendly corrosion inhibitor for mild steel in 1 M sulfuric acid medium. Mater. Corros. 2009, 60, 22-28, https://doi.org/10.1002/maco.200805027.

39. Grassino, A.N.; Grabaric, Z.; Pezzani, A.; Fasanaro, G. Influence of Essential Onion Oil on Tin and Chromium Dissolution From Tinplate. Food Chem. Toxicol. 2009, 47, 15561561,https://doi.org/10.1016/j.fct.2009.04.003.

40. Buchweishaija, J.; Mihinji, G.S. Natural Products as a Source of Environmentally Friendly Corrosion Inhibitors. Portugaliae Electrochim. Acta2008, 26, 257-265.

41. Hamdan, A.B.; Haider, F.I. Study on tea leaves extract as green corrosion inhibitor of mild steel in hydrochloric acid solution. IOP Conf. Ser. Mater. Sci. Eng. 2018, 290, 12-86, https://doi.org/10.1088/1757899X/290/1/012086. 
42. Gibot, P.; Vidal, L. Original synthesis of chromium (III) oxide nanoparticles. J Eur Ceram Soc. 2010, 30, 911-915,https://doi.org/10.1016/j.jeurceramsoc.2009.09.019.

43. Makhlouf, S.A.; Bakra, Z.H.; Al-attara, H.; Moustafaa, M.S. Structural, morphological and electrical properties of $\mathrm{Cr}_{2} \mathrm{O}_{3}$ nanoparticles. Mater Sci Eng. 2013, 178, 337343,https://doi.org/10.1016/j.mseb.2013.01.012.

44. Pan, Y.; Neuss, S.; Leifer, A. Size-dependent cytotoxicity of gold nanoparticles. Small2007, 3, 19411949,https://doi.org/10.1002/smll.200700378.

45. Zhang, Y.; Xu, D.; Li, W.; Yu, J. Chen Yu. Effect of size, shape, and surface modification on cytotoxicity of gold nanoparticles to human HEp-2 and canine MDCK cells. J. Nanomater2012, 2012, https://doi.org/10.1155/2012/375496.

46. Borm, P.J.; Robbins, D.; Haubold, S. The potential risks of nanomaterials: a review carried out for ECETOC.Part Fibre.Toxicol. 2006, 3, https://doi.org/10.1186/1743-8977-3-11.

47. Warheit, D.B.; Laurence, B.R.; Reed, K.L. Comparative pulmonary toxicity assessment of single-wall carbon nanotubes in rats. Toxicol Sci. 2004, 77, 117-125,https://doi.org/10.1093/toxsci/kfg228.

48. Oberdorster, G.; Oberdorster, E.; Oberdorster, J. Nanotoxicology: an emerging discipline evolving from studies of ultrafine particles. Environ Health Perspect. 2005, 113, 823839,https://doi.org/10.1289/ehp.7339.

49. Krewski, D.; Westphal, M.; Al-Zoughool, M.; Croteau, M.C.; Andersen, M.E. New directions in toxicity testing. Annu Rev Public Health, 2011, 32, 161-178, https://doi.org/10.1146/annurev-publhealth-031210101153.

50. Lin, W.; Huang, Y.W.; Zhou, X.D. In vitro toxicity of silica nanoparticles in human lung cancer cells. Toxicol. Appl. Pharmacol. 2006, 217, 252-259,https://doi.org/10.1016/j.taap.2006.10.004.

51. Wang, C.; Hu, X.; Gao, Y.; Ji, Y. ZnO nanoparticles treatment induces apoptosis by increasing intracellular ROS levels in LTEP-a-2 Cells. Biomed Res Int. 2015, 2015, https://doi.org/10.1155/2015/423287.

52. Sangeetha, J.; Sandhya, J.; Philip, J. Biosynthesis and Functionalization of Silver Nanoparticles Using Nigellasativa, Dioscorea alata and Ferula asafoetida. Science of Advanced Materials2014, 6, 16811691,https://doi.org/10.1166/sam.2014.1991.

53. Mosmann, T. Rapid Colorimetric Assay for Cellular Growth and Survival: Application to Proliferation and Cytotoxicity Assays. Journal of Immunological Methods1983, 65, 55-63,https://doi.org/10.1016/00221759(83)90303-4.

54. Abdel Hameed, R.S.; Al-shafey, H.I. Nano-composite as corrosion inhibitors for steel alloys in different corrosive media. Advances in Applied Science Research. 2013, 4, 126-129.

55. Vilchis-Nestor, A.R.; Sánchez-Mendieta, V.; Camacho-López, M.A.; Gómez-Espinosa, R.M.; CamachoLópez, M.A.; Arenas-Alatorre, J.A. Solvent less synthesis and optical properties of Au and Ag nanoparticles using Camellia sinensis. Materials Letters 2008, 62, 3103-3105, https://doi.org/10.1016/j.matlet.2008.01.138.

56. Tripathy, A.; Raichur, A.M.; Chandrasekaran, N.; Prathna, T.C.; Mukherjee, A. Process variables in biomimetic synthesis of silver nanoparticles by aqueous extract of Azadirachta indica (Neem) leaves. Journal of Nanoparticle Research2010, 12, 237-246, https://doi.org/10.1007/s11051-009-9602-5.

57. Vanaja, M.; Annadurai, G. Coleus aromaticus leaf extract mediated synthesis of silver nanoparticles and its bactericidal activity. Applied Nanoscience2013, 3, 217-223,https://doi.org/10.1007/s13204-012-0121-9.

58. Reenaa, M.; Menon, A.S. Synthesis of Silver Nanoparticles from Different Citrus Fruit Peel Extracts and a Comparative Analysis on its Antibacterial Activity. International Journal of Current Microbiology and Applied Sciences2017, 6, 2358-2365,https://doi.org/10.20546/ijcmas.2017.607.337.

59. Faedmaleki, F.; Shirazi, F.H.; Salarian, A.A.; Ashtiani, H.A.; Rastegar, H. Toxicity effect of silver nanoparticles on mice liver primary cell culture and HepG2 cell line. Iranian Journal of Pharmaceutical Research 2014, 13, 235-242.

60. Braydich-Stolle, L.; Hussain, S.; Schlager, J.J.; Hofmann, M.C. In Vitro Cytotoxicity of Nanoparticles in Mammalian Germline Stem Cells. Toxicological Sciences2005, 88, 412419,https://doi.org/10.1093/toxsci/kfi256. 